\title{
Sweet's syndrome in a 45-year-old patient
}

\section{Zespół Sweeta u 45-letniego pacjenta}

\author{
Dorota Kozłowska, Agnieszka B. Serwin, Iwona Flisiak \\ Department of Dermatology and Venereology, Medical University of Bialystok, Poland \\ Klinika Dermatologii i Wenerologii, Uniwersytet Medyczny w Białymstoku, Polska
}

Dermatol Rev/Przegl Dermatol 2020, 107, 469-475

DOI: https://doi.org/l0.5 | |4/dr.2020.101676

\author{
CORRESPONDING AUTHOR/ \\ ADRES DO KORESPONDENCJI: \\ lek. Dorota Kozłowska \\ Klinika Dermatologii \\ i Wenerologii \\ Uniwersytet Medyczny \\ w Białymstoku \\ ul. Żurawia 14 \\ 15-540 Białystok \\ tel.: +48508182954 \\ e-mail: dorota.kozlowska@umb. \\ edu.pl
}

\begin{abstract}
Introduction. Sweet's syndrome, also known as acute febrile neutrophilic dermatosis, is a rare neutrophilic dermatosis of sudden onset. The disease may be induced by preceding infectious diseases, coexist with autoimmune diseases, be a revelator of proliferative diseases, and also be provoked by drugs.
\end{abstract}

Objective. To present a case of a patient with Sweet's syndrome successfully treated with prednisone and dapsone.

Case report. A forty-five-year-old man was admitted to the Department of Dermatology and Venereology for the differential diagnosis and treatment of skin lesions that had persisted for a month. Sweet's syndrome was diagnosed on the basis of the clinical presentation and histopathology. All skin lesions resolved after tretment with prednisone and dapsone.

Conclusions. Oral glucocorticosteroids are the first-line therapy, and improvement in the local condition is observed during the first few days of treatment. Because of the possible comorbidities, which include neoplastic diseases, patients with Sweet's syndrome require thorough work-up and long-term follow-up after treatment.

\section{STRESZCZENIE}

Wprowadzenie. Zespół Sweeta, zwany ostrą gorączkową dermatozą neutrofilową, należy do rzadkich dermatoz neutrofilowych o nagłym początku. Choroba może być indukowana poprzedzającymi schorzeniami infekcyjnymi, współistnieć z chorobami autoimmunologicznymi, być rewelatorem chorób rozrostowych, a także być prowokowana przez leki.

Cel pracy. Przedstawienie przypadku pacjenta z zespołem Sweeta skutecznie leczonego prednizonem i dapsonem.

Opis przypadku. Czterdziestopięcioletni mężczyzna został przyjęty do Kliniki Dermatologii i Wenerologii w celu diagnostyki i leczenia zmian skórnych utrzymujących się od miesiąca. Na podstawie obrazu klinicznego oraz wyniku badania histopatologicznego rozpoznano zespół Sweeta. Zmiany skórne ustąpiły całkowicie po włączeniu prednizonu i dapsonu.

Wnioski. Glikokortykosteroidy doustne stanowią terapię pierwszego wyboru, a poprawę stanu miejscowego obserwuje się w czasie kilku pierwszych dni leczenia. Ze względu na możliwość współwystępowania wielu chorób, w tym nowotworów, pacjenci z zespołem Sweeta wymagają dokładnej diagnostyki i długofalowej obserwacji po leczeniu.

Key words: prednisone, neutrophilic dermatoses, Sweet's syndrome. Słowa kluczowe: prednizon, dermatozy neutrofilowe, zespół Sweeta. 


\section{INTRODUCTION}

Sweet's syndrome, also known as acute febrile neutrophilic dermatosis, belongs to the group of neutrophilic dermatoses characterized by a sudden onset. The disease usually affects patients between 30 and 60 years of age, and may also affect children. Pediatric cases constitute $5 \%$ of all cases [1]. It is more common in women than in men, with the incidence ratio of $3.7: 1$ [2]. It is clinically manifested by the presence of painful erythematous-edematous papules and nodules, as well as tender inflammatory infiltrative foci accompanied by fever and neutrophilia. They may be preceded by the occurrence of flu-like symptoms [3]. Skin eruptions are located asymmetrically, mainly in the limbs, face and neck. Patients with Sweet's syndrome may exhibit a symptom of pathergy [4].

In Sweet's syndrome, changes in the oral mucosa may be present, observed in approximately $12 \%$ of patients with coexisting cancer. Neutrophilic infiltrates may also be present in other organs such as the eyes, muscles, lungs, liver, spleen, central nervous and digestive systems. The most common extra-cutaneous manifestation is eye involvement, manifesting itself as conjunctivitis, scleritis, choroiditis or ulcerative keratitis [5].

Pathogenesis of the disease is unknown. It is believed that genetic factors, hypersensitivity reactions to bacterial and viral antigens, cancer cells, and dysregulation of cytokines promoting the inflammatory response are involved in the development of the disease [3]. Sweet's syndrome can be induced by a past infection, coexist with autoimmune diseases, be a revelator of proliferative diseases, and also be provoked by drugs [6].

The diagnosis is made on the basis of the typical clinical and histopathological presentation. The microscopic image shows a dense infiltration of neutrophils in the superficial and middle part of the dermis with no visible signs of vasculitis (tables 1,2$)[7,8]$.

\section{OBJECTIVE}

To show a patient with Sweet's syndrome successfully treated with prednisone and dapsone.

\section{CASE REPORT}

The forty-five-year-old man, previously healthy, came to the Teaching Department of Dermatology and Venereology for the diagnosis and treatment of skin lesions that had persisted for a month. Eruptions initially appeared on the skin of the trunk, then on the upper and lower limbs and buttocks. The patient did not provide a tangible cause for the appearance of

\section{WPROWADZENIE}

Zespół Sweeta, zwany ostrą gorączkową dermatozą neutrofilową (acute febrile neutrophilic dermatosis), należy do dermatoz neutrofilowych o nagłym początku. Chorobę zwykle stwierdza się u pacjentów od 30. do 60. roku życia, może ona dotyczyć także dzieci. Przypadki pediatryczne stanowią $5 \%$ wszystkich przypadków [1]. Zespół Sweeta występuje częściej u kobiet niż mężczyzn, stosunek zachorowań wynosi 3,7 : 1 [2]. Klinicznie objawia się obecnością bolesnych, rumieniowo-obrzękowych grudek i guzków, a także tkliwych zapalnych ognisk naciekowych z towarzyszącą gorączką i neutrofilią. Mogą one być poprzedzone wystąpieniem objawów grypopodobnych [3]. Wykwity skórne lokalizują się asymetrycznie, głównie w obrębie kończyn, twarzy i szyi. U pacjentów z zespołem Sweeta może występować objaw patergii [4].

W przebiegu zespołu Sweeta mogą być obecne zmiany na błonie śluzowej jamy ustnej, obserwowane u ok. $12 \%$ pacjentów ze współistniejącą chorobą nowotworową. Nacieki neutrofilowe stwierdza się również w obrębie innych narządów: wzroku, mięśniach, płucach, wątrobie, śledzionie, ośrodkowym układzie nerwowym i układzie pokarmowym. Najczęstszą manifestacją pozaskórną jest zajęcie narządu wzroku objawiające się jako zapalenie spojówek, twardówki, naczyniówki lub wrzodziejące zapalenie rogówki [5].

Patogeneza choroby nie jest znana. Przypuszcza się, że w jej rozwoju biorą udział czynniki genetyczne, reakcje nadwrażliwości na antygeny bakteryjne, wirusowe, komórki nowotworowe, a także dysregulacja cytokin promujących odpowiedź zapalną [3]. Zespół Sweeta może być indukowany przebytą infekcją, współistnieć z chorobami autoimmunologicznymi, być rewelatorem chorób rozrostowych, a także może być prowokowany przez leki [6].

Rozpoznanie ustala się na podstawie typowego obrazu klinicznego i histopatologicznego. Obraz mikroskopowy uwidacznia gęsty naciek neutrofilów w powierzchownej i środkowej części skóry właściwej bez widocznych cech zapalenia naczyń (tab. 1, 2) [7, 8].

\section{CEL PRACY}

Przedstawienie pacjenta z zespołem Sweeta skutecznie leczonego za pomocą prednizonu i dapsonu.

\section{OPIS PRZYPADKU}

Czterdziestopięcioletni mężczyzna, dotychczas zdrowy, zgłosił się do Kliniki Dermatologii i Wenerologii w celu diagnostyki i leczenia zmian skórnych utrzymujących się od miesiąca. Wykwity początkowo pojawiły się w obrębie skóry tułowia, następnie kończyn górnych, dolnych i pośladków. Pacjent nie poda- 
Table I. Diagnostic criteria for Sweet syndrome (classical and malignancy-associated)*

Tabela I. Kryteria rozpoznania zespołu Sweeta (typ klasyczny i związany z nowotworem)*

\begin{tabular}{|c|}
\hline Major criteria/Kryteria duże \\
\hline $\begin{array}{l}\text { I. Sudden onset of painful skin changes such as papules, nodules and inflammatory infiltrates/Nagły początek bolesnych zmian } \\
\text { skórnych w postaci grudek, guzków oraz nacieków zapalnych }\end{array}$ \\
\hline $\begin{array}{l}\text { 2. Typical histopathological presentation: dense neutrophilic infiltration in the dermis without leukocytoclastic vasculitis/Typowy obraz } \\
\text { histopatologiczny: gęsty naciek neutrofilowy w skórze właściwej bez cech leukocytoklastycznego zapalenia naczyń }\end{array}$ \\
\hline Minor criteria/Kryteria mniejsze \\
\hline I. Fever/Gorączka \\
\hline $\begin{array}{l}\text { 2. Coexistence of cancer, inflammatory bowel disease, pregnancy, confirmation of an upper respiratory or gastrointestinal infection/ } \\
\text { Wspótistnienie choroby nowotworowej, choroby zapalnej jelit, ciąży, potwierdzonej infekcji górnych dróg oddechowych lub } \\
\text { przewodu pokarmowego }\end{array}$ \\
\hline $\begin{array}{l}\text { 3. Very quick response to systemic treatment with glucocorticosteroids or potassium iodide/Bardzo szybka odpowiedź na ogólne } \\
\text { leczenie glikokortykosteroidami lub jodkiem potasu }\end{array}$ \\
\hline $\begin{array}{l}\text { 4. Laboratory abnormalities (3 of 4): ESR > } 20 \mathrm{~mm} / \mathrm{h} ; \uparrow \text { CRP; leukocytes }>8000 / \mu \mathrm{l} \text { as in the text; neutrophilia }>70 \% / \\
\text { Nieprawidłowości w badaniach laboratoryjnych (3 z 4): OB > } 20 \mathrm{~mm} / \mathrm{godz} . ; \uparrow \text { CRP; leukocyty }>8000 / \mu \mathrm{l} \mathrm{jak} \mathrm{w} \mathrm{tekście;} \mathrm{neutrofilia} \\
>70 \%\end{array}$ \\
\hline
\end{tabular}

Tabela 2. Kryteria rozpoznania zespołu Sweeta indukowanego lekami*

Table 2. Diagnostic criteria for drug-induced Sweet syndrome*

\begin{tabular}{l}
\hline $\begin{array}{l}\text { I. Sudden onset of painful skin changes such as papules, nodules and inflammatory infiltrates/Nagły początek bolesnych zmian } \\
\text { skórnych: grudek, guzków oraz nacieków zapalnych }\end{array}$ \\
\hline $\begin{array}{l}\text { 2. Typical histopathological presentation: dense neutrophilic infiltration in the dermis without leukocytoclastic vasculitis/Typowy obraz } \\
\text { histopatologiczny: gęsty naciek neutrofilowy w skórze właściwej bez cech leukocytoklastycznego zapalenia naczyń }\end{array}$ \\
\hline 3. Fever $>38^{\circ} \mathrm{C} /$ Gorączka $>38^{\circ} \mathrm{C}$ \\
\hline 4. Time relationship between symptom onset and medication intake or drug-related relapse/Związek czasowy pomiędzy \\
wystąpieniem objawów a przyjmowaniem leków lub nawrót zmian związany z przyjęciem leków \\
\hline 5. Resolution of skin lesions after discontinuation of drugs or after treatment with general glucocorticoids/Ustąpienie zmian skórnych \\
po odstawieniu leków lub po leczeniu glikokortykosteroidami ogólnie \\
*All criteria have to be met to diagnose drug-induced Sweet's syndrome/Spetnienie wszystkich kryteriów pozwala na rozpoznanie zespołu Sweeta indukowanego lekami.
\end{tabular}

changes, negated previous infections, and took painkillers on an ad hoc basis. In the outpatient setting, he was treated with oral antihistamines (bilastine), topically he used betamethasone dipropionate with gentamicin without any improvement.

On admission to the Department, the skin of the neck, torso, buttocks and extremities was characterized by numerous scattered, oval erythematousedematous foci with the presence of pustules and vesicles around the perimeter (figs. 1, 2), as well as single well-taut blisters filled with serous contents (fig. 3). Skin lesions were itchy and mildly painful. The patient did not report any visual symptoms. On the second day of hospitalization, the patient developed a fever. Laboratory tests revealed leukocytosis with neutrophilia (WBC 13.33 thousand/ $\mu$ l, NEU 10.2 thousand $/ \mu 1$, NEU $75 \%$ ), as well as an increased concentration of C-reactive protein $(53.13 \mathrm{mg} / 1$, normal range $<5.0 \mathrm{mg} / \mathrm{l}$ ) and the activity of lactate dehydrogenase $367 \mathrm{U} / 1$ (normal range: 135-225 U/1). Other parameters assessing functions of the liver, kidneys, electrolytes, lipid metabolism, tumor markers and wał uchwytnej przyczyny pojawienia się zmian, negował poprzedzające infekcje, doraźnie przyjmował leki przeciwbólowe. W warunkach ambulatoryjnych był leczony za pomocą doustnych preparatów przeciwhistaminowych (bilastyna), miejscowo stosował dipropionian betametazonu z gentamycyną bez poprawy.

Przy przyjęciu do Kliniki w obrębie skóry szyi, tułowia, pośladków oraz kończyn stwierdzono liczne rozsiane, owalne ogniska rumieniowo-obrzękowe $\mathrm{z}$ obecnością krost i pęcherzyków na obwodzie (ryc. 1, 2), a także pojedyncze dobrze napięte pęcherze wypełnione treścią surowiczą (ryc. 3). Zmianom skórnym towarzyszył świąd oraz niewielka bolesność. Chory nie zgłaszał dolegliwości ze strony narządu wzroku. W drugiej dobie hospitalizacji pacjent zaczął gorączkować. W badaniach laboratoryjnych z odchyleń od stanu prawidłowego stwierdzono leukocytozę z neutrofilią (WBC 13,33 tys./ $\mu \mathrm{l}$, NEU 10,2 tys./ $\mu \mathrm{l}$, NEU 75\%), a także podwyższone stężenie białka C-reaktywnego (53,13 mg/1, norma < 5,0 mg/1) i zwiększoną aktywność dehydrogenazy mleczanowej (367 U/1, norma: 135-225 U/1). Pozostałe parametry oceniające funkcje 


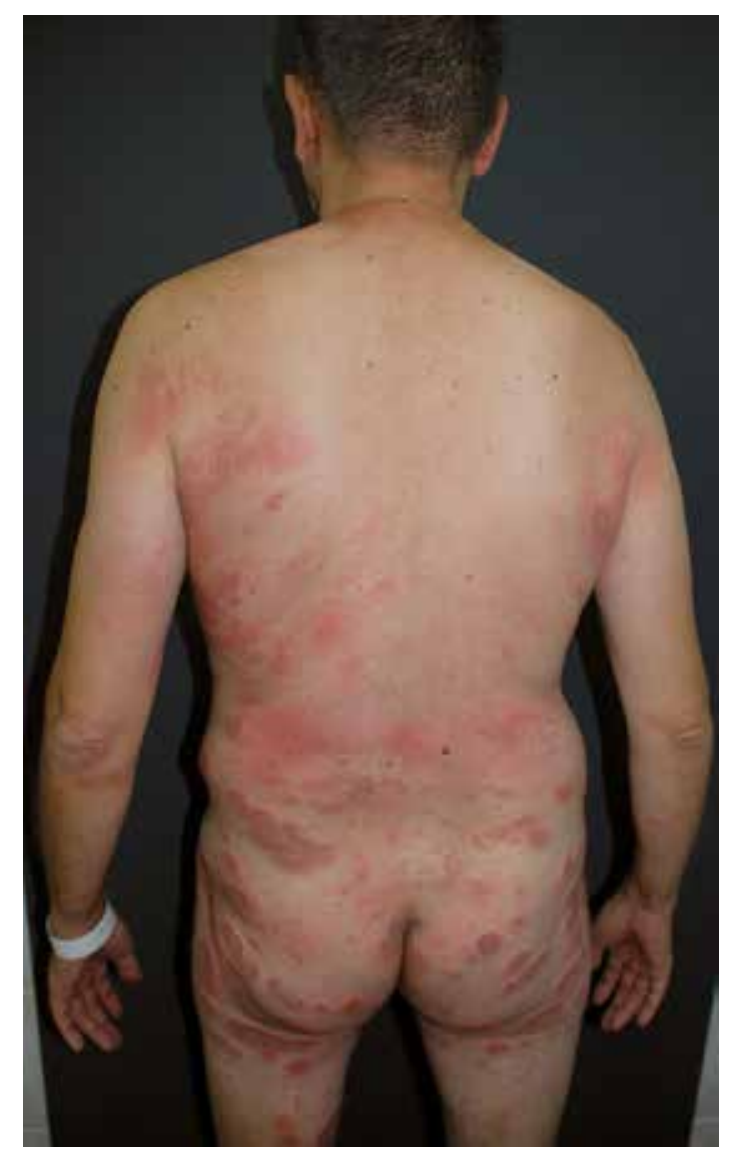

Figure I. Numerous erythematous edema skin lesions in the skin of the back, buttocks and lower extremities

Rycina I. Liczne zmiany rumieniowo-obrzękowe w obrębie skóry pleców, pośladków i kończyn dolnych

chest X-ray examination were normal. Antibodies against Chlamydia pneumoniae and Chlamydia trachomatis in the IgG class and against EBV-VCA in the IgM class were within the normal range. The histopathological examination of skin lesions revealed perivascular and scattered infiltrates of lymphoid cells and neutrophilic and acidophilic granulocytes. In the epidermis, there were vesicles filled with granulocytes and subcorneal micro-abscesses (fig. 4). Because of the necessity to exclude blistering diseases (including linear IgA bullous dermatosis), a biopsy was taken for immunopathological examination. The examination detected no immunological phenomena. In general treatment, prednisone was used at the initial dose of $0.5 \mathrm{mg} / \mathrm{kg}$, dapsone at the dose of $50 \mathrm{mg} /$ day with vitamin E supplementation, anti-histamine preparations and proton pump inhibitors. In the topical treatment, glucocorticosteroids and emollients were used. After several days of hospitalization, a significant local improvement was observed (fig. 5). During follow-up visits, leukocytosis with neutrophilia was found in the blood count. Dapsone was discontinued on day 28 due to an increase in

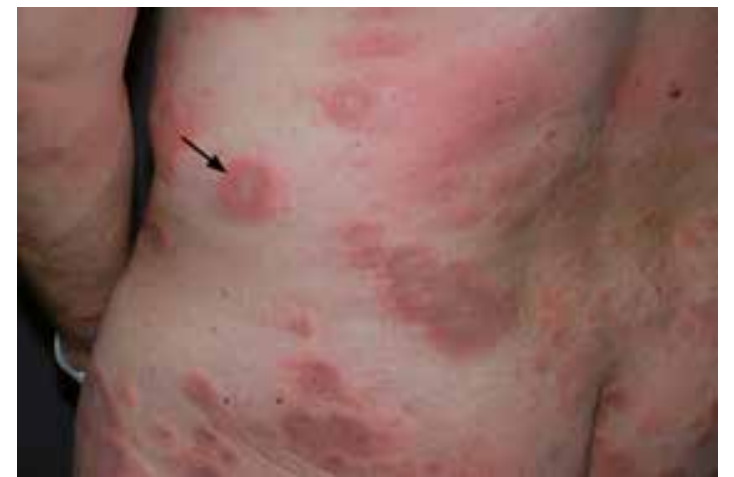

Figure 2. Numerous peripheral pustules within erythematous edema skin lesions (arrow)

Rycina 2. Liczne krosty na obwodzie zmian rumieniowo-obrzękowych (strzałka)

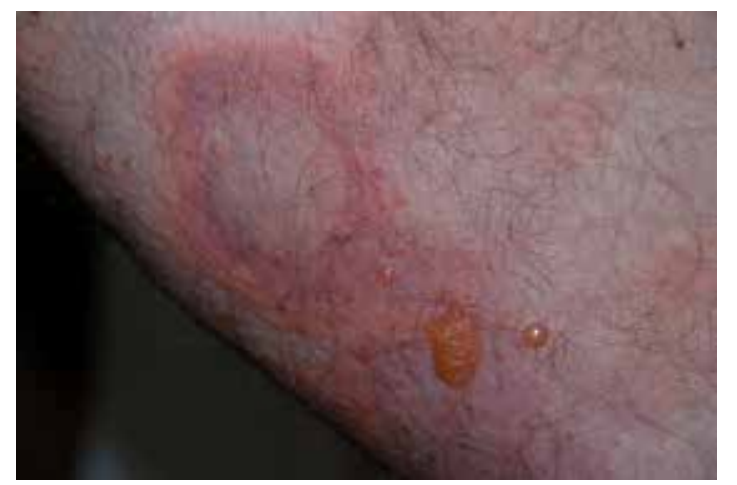

Figure 3. Erythematous skin lesions with the presence of single well tense blisters in the skin of trunk

Rycina 3. Zmiany rumieniowe z obecnością pojedynczych dobrze napiętych pęcherzy w obrębie skóry tułowia

wątroby, nerek, elektrolity, gospodarkę lipidową, markery nowotworowe oraz badanie rentgenograficzne klatki piersiowej były prawidłowe. Przeciwciała przeciwko Chlamydia pneumoniae oraz Chlamydia trachomatis w klasie IgG oraz przeciwko EBV-VCA w klasie IgM były $\mathrm{w}$ granicach normy. $\mathrm{W}$ badaniu histopatologicznym ze zmiany skórnej stwierdzono okołonaczyniowe i rozproszone w powierzchownych warstwach skóry nacieki z komórek limfoidalnych oraz granulocytów kwaso- i obojętnochłonnych. W naskórku obecne były pęcherzyki wypełnione granulocytami i mikroropnie podrogowe (ryc. 4). Ze względu na konieczność wykluczenia chorób pęcherzowych (w tym linijnej IgA dermatozy pęcherzowej) pobrano wycinek do badania immunopatologicznego, które było ujemne. W leczeniu ogólnym zastosowano prednizon $\mathrm{w}$ wyjściowej dawce $0,5 \mathrm{mg} / \mathrm{kg}$, dapson w dawce $50 \mathrm{mg} /$ dobę z suplementacją witaminą $\mathrm{E}$, preparaty przeciwhistaminowe oraz inhibitory pompy protonowej. W leczeniu miejscowym użyto preparatów glikokortykosteroidowych oraz emolientów. Po kilkudniowej hospitalizacji obserwowano znaczną poprawę miejscową (ryc. 5). W czasie wizyt kontrolnych stwierdzono utrzymującą się w morfologii 


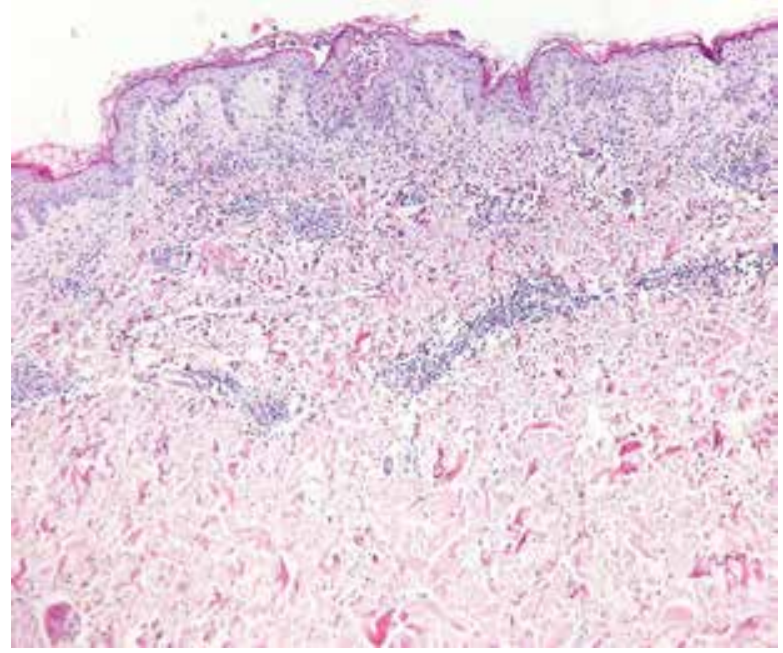

Figure 4. Perivascular and diffuse infiltrates of lymphoid cells and neutrophils in the superficial layers of the dermis (magnification 10x)

Rycina 4. Okołonaczyniowe i rozproszone w powierzchownych warstwach skóry nacieki z komórek limfoidalnych i granulocytów obojętnochłonnych (powiększenie I0×)

the percentage of methemoglobin in the blood (over $3 \%$ ). The patient continued treatment with gradually reduced doses of prednisone for 6 weeks. No recurrence of changes was observed.

\section{DISCUSSION}

The diagnosis in the presented patient was made on the basis of a typical histopathological presentation, as well as the fulfillment of two large and three small criteria for diagnosis (table 1).

In the presented patient, numerous pustules, vesicles and single, well-taut blisters were observed, which is a less frequent clinical manifestation. Within skin lesions, patients with Sweet's syndrome report pain associated with skin eruptions as tenderness and burning sensation, and approximately $18 \%$ of patients report skin itching [9].

There are three clinical subtypes of Sweet's syndrome - the first one - classic, also called idiopathic, is the most common. Symptoms of the disease are usually associated with a previous infection of the upper respiratory tract, digestive system, coexistence of inflammatory bowel diseases or pregnancy [10]. Less frequently, it may be associated with systemic autoimmune diseases, including systemic lupus erythematosus, Behçet's disease, rheumatoid arthritis and sarcoidosis [11]. The second subtype is Sweet's cancer-related syndrome. Patients are most often diagnosed with hematopoietic hyperplastic diseases, including acute myeloid leukemia, myelodysplastic syndrome, multiple myeloma, and, slightly less fre-

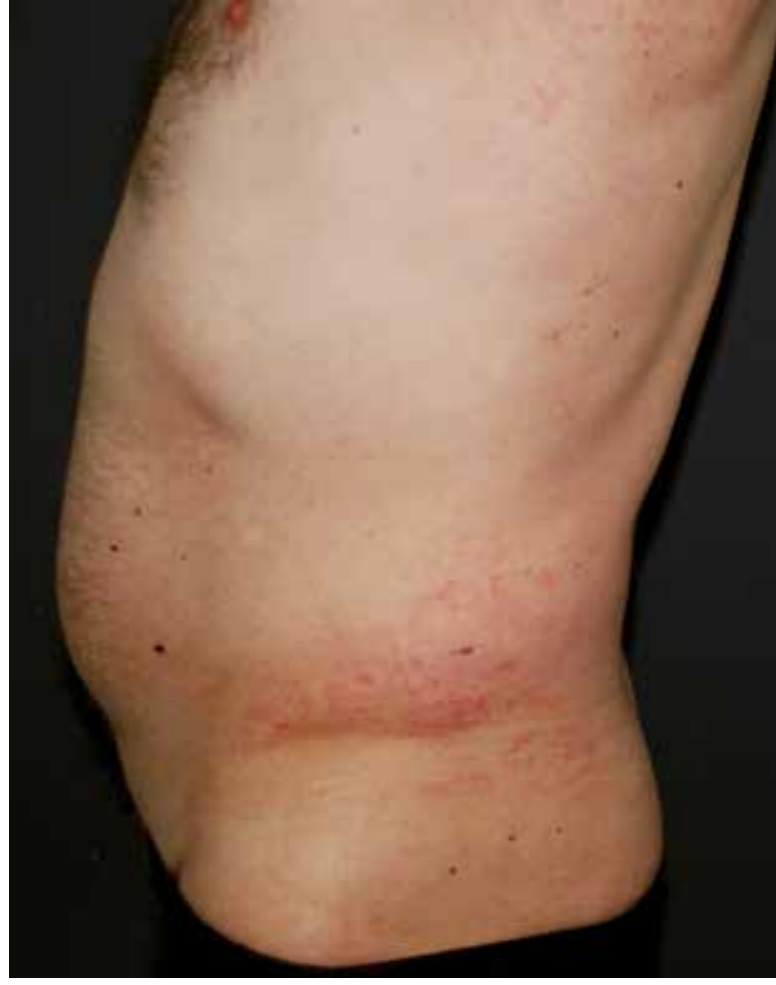

Figure 5. Nearly complete remission of the skin lesions after few days of treatment with prednisone and dapsone

Rycina 5. Niemal całkowita remisja zmian skórnych po kilkudniowym leczeniu prednizonem i dapsonem

krwi leukocytozę z neutrofilią. Dapson został odstawiony w 28. dniu z powodu wzrostu odsetka methemoglobiny we krwi (powyżej 3\%). Pacjent kontynuował leczenie prednizonem w stopniowo zmniejszanych dawkach przez 6 tygodni. Nie obserwowano nawrotu zmian.

\section{OMÓWIENIE}

Rozpoznanie choroby u przedstawionego pacjenta ustalono na podstawie typowego obrazu histopatologicznego, a także spełnienia dwóch dużych i trzech małych kryteriów diagnostycznych (tab. 1).

U chorego obserwowano liczne krosty, pęcherzyki i pojedyncze dobrze napięte pęcherze, co stanowi rzadszą manifestację kliniczną. Pacjenci z zespołem Sweeta odczuwają ból w obrębie zmian skórnych opisywany jako tkliwość i uczucie pieczenia, a ok. 18\% pacjentów zgłasza świąd skóry [9].

Wyróżnia się trzy podtypy kliniczne zespołu Sweeta. Podtyp pierwszy - klasyczny, zwany również idiopatycznym, występuje najczęściej. Objawy choroby są zwykle związane z przebytą infekcją górnych dróg oddechowych, układu pokarmowego, współwystępowaniem chorób zapalnych jelit i ciążą [10]. Nieco rzadziej mogą mieć zwiazek z układowymi chorobami autoimmunologicznymi, $\mathrm{w}$ tym toczniem rumieniowatym 
Table 3. Groups of drugs provoked Sweet's syndrome

Tabela 3. Grupy leków prowokujących zespół Sweeta

\begin{tabular}{|c|c|}
\hline Group/Grupa & Leki/Drugs \\
\hline Anti-cancer/Przeciwnowotworowe & $\begin{array}{l}\text { Bortezomib, imatinib, ipilimumab, lenalidomid, topotecan, vemurafenib/ Bortezomib, } \\
\text { imatynib, ipilimumab, lenalidomid, topotekan, wemurafenib }\end{array}$ \\
\hline Antipsychotic/Przeciwpsychotyczne & Clozapine/Klozapina \\
\hline Anti-thyroid/Przeciwtarczycowe & Propylotiouracyl/Propylotiouracyl \\
\hline Growth factors/Czynniki wzrostu & $\begin{array}{l}\text { Granulocyte colony stimulating factor (G-CSF), granulocyte and macrophage colony } \\
\text { stimulating factor, pegfilgrastym/Czynnik stymulujący wzrost kolonii granulocytów } \\
\text { (G-CSF), czynnik stymulujący tworzenie kolonii granulocytów i makrofagów, pegfilgrastym }\end{array}$ \\
\hline Contraceptives/Środki antykoncepcyjne & Levonorgestrel, etynyloestradiol/Lewonorgestrel, etynyloestradiol \\
\hline Diuretics/Diuretyki & Furosemide/Furosemid \\
\hline Immunosuppressants/Leki immunosupresyjne & Azathioprin/Azatiopryna \\
\hline $\begin{array}{l}\text { Non-steroid anti-infammatory drugs/ } \\
\text { Niesteroidowe leki przeciwzapalne }\end{array}$ & Celekoxyb, diclofenac/Celekoksyb, diklofenak \\
\hline Retinoids/Retinoidy & All-trans-retinoic acid, I3-cis-retinoic acid/Kwas all-trans-retinowy, kwas I3-cis-retinowy \\
\hline
\end{tabular}

quently, solid tumors $[12,13]$. The third type of disease is drug-induced Sweet's syndrome. Symptoms of the disease usually appear about 14 days after exposure to a given drug (table 3) [14].

In the treatment of Sweet's syndrome, prednisone orally at the dose of $0.5-1 \mathrm{mg} / \mathrm{kg} \mathrm{b.w./day} \mathrm{is}$ recommended. If less than $5 \%$ of the skin surface is involved, topical medium and high-power corticosteroids can be used. Improvement of the skin condition is achieved very quickly (in about 2 days), which was also observed in the presented case. Alternatives to oral glucocorticosteroids can be: dapsone, colchicine, and potassium iodide. If left untreated, Sweet's syndrome can go into remission within weeks to months. Relapses of the disease are rare, and they more often affect patients with concomitant cancers [9].

In the case of the described patient, no clear causative factor causing the symptoms of the disease has been established. The patient remains under a constant control of the Teaching Department of Dermatology, and the disease is now in remission. If leukocytosis with neutrophilia persists, the patient will be referred to the Hematology Outpatient Clinic for further diagnosis. The patient was initially treated with the empirical combination of prednisone and dapsone before obtaining the results of histopathological and immunopathological examination.

\section{CONCLUSIONS}

Sweet's syndrome is a rare disease, sometimes severe, associated with fever, muscle and joint pain and development of neutrophilic infiltrates in many extra-cutaneous organs. Due to the risk of developing cancer and autoimmune diseases, patients may require multi-specialist care, in-depth diagnostics and układowym, chorobą Behçeta, reumatoidalnym zapaleniem stawów i sarkoidozą [11]. Drugi podtyp to zespół Sweeta związany z chorobami nowotworowymi. U pacjentów najczęściej rozpoznaje się choroby rozrostowe układu krwiotwórczego, w tym ostrą białaczkę szpikową, zespół mielodysplastyczny, szpiczaka mnogiego, nieco rzadziej guzy lite $[12,13]$. Trzeci podtyp choroby to zespół Sweeta indukowany lekami. Objawy zwykle występują ok. 14 dni po ekspozycji na lek (tab. 3) [14].

W leczeniu zespołu Sweeta zaleca się stosowanie prednizonu doustnie $\mathrm{w}$ dawce $0,5-1 \mathrm{mg} / \mathrm{kg}$ m.c./ dobę. W przypadku zajęcia poniżej $5 \%$ powierzchni skóry można zastosować miejscowo glikokortykosteroidy średniej i dużej mocy. Poprawę stanu skóry osiąga się bardzo szybko (po ok. 2 dniach), co również obserwowano u prezentowanego pacjenta. Inne metody leczenia to: dapson, kolchicyna i jodek potasu. Nieleczony zespół Sweeta może ulec samoistnej remisji w czasie od kilku tygodni do kilku miesięcy. Nawroty choroby są rzadkie, częściej występują u pacjentów ze współistniejącą chorobą nowotworową [9].

W przypadku opisywanego pacjenta nie ustalono ewidentnego czynnika sprawczego. Mężczyzna jest pod stałą kontrolą poradni dermatologicznej, obecnie obserwuje się remisję choroby. W przypadku utrzymywania się leukocytozy z neutrofilią zostanie skierowany do poradni hematologicznej w celu pogłębienia diagnostyki. U chorego zastosowano wyjściowo empiryczne leczenie skojarzone za pomocą prednizonu i dapsonu przed otrzymaniem wyniku badania histopatologicznego oraz immunopatologicznego.

\section{WNIOSKI}

Zespół Sweeta to rzadka jednostka chorobowa, niekiedy o ciężkim przebiegu - z gorączką, bólami mięśniowo-stawowymi i rozwojem nacieków neutro- 
long-term follow-up. The prognosis of the disease is usually good and it is not life-threatening if coexisting proliferative disease is excluded.

\section{ACKNOWLEDGMENTS}

Authors thank Dr. Agata Piłaszewicz-Puza of the Medical Pathomorphology Laboratory of the Medical University in Bialystok for microscopic images.

\section{CONFLICT OF INTEREST}

The authors declare no conflict of interest. filowych w wielu narządach poza skórą. Ze względu na ryzyko rozwoju chorób nowotworowych oraz autoimmunologicznych pacjenci mogą wymagać wielospecjalistycznej opieki i dogłębnej diagnostyki oraz długofalowej obserwacji. W przypadku wykluczenia współistniejącej choroby rozrostowej rokowanie zwykle jest dobre, choroba nie zagraża życiu pacjenta.

\section{PODZIĘKOWANIA}

Autorzy dziękują dr Agacie Piłaszewicz-Puzie z Zakładu Patomorfologii Lekarskiej Uniwersytetu Medycznego w Białymstoku za przygotowanie i wykonanie zdjęcia mikroskopowego.

\section{KONFLIKT INTERESÓW}

Autorzy nie zgłaszają konfliktu interesów.

\section{References}

\section{Piśmiennictwo}

1. Stevens G.J., Yutronic H.J., Pizarro O.J., Velozo P.L.: Sweet syndrome in pediatrics. A case report. Rev Chil Pediatr 2018, 89, 511-515.

2. Lima C.D., Pinto R.D., Góes H.F., Salles S.A., Vilar E.A., Lima C.D.: Sweet's syndrome associated with Crohn's disease. An Bras Dermatol 2017, 92, 263-265.

3. Villarreal-Villarreal C.D., Ocampo-Candiani J., Villarreal-Martínez A.: Sweet syndrome: a review and update. Actas Dermosifiliogr 2016, 107, 369-378.

4. Halpern J., Salim A.: Pediatric sweet syndrome: case report and literature review. Pediatr Dermatol 2009, 26, 452-457.

5. Díaz-Peromingo J.A., García-Suárez F., Sánchez-Leira J., Saborido-Froján Y.: Sweet's syndrome in a patient with acute ulcerative colitis: presentation of a case and review of the literature. J Biol Med 2001, 74, 165-168.

6. Treton X., Joly F., Alves A., Panis Y., Bouhnik Y.: Azathioprine-induced Sweet's syndrome in Crohn's disease. Inflamm Bowel Dis 2008, 14, 1757-1758.

7. von den Driesch P.: Sweet's syndrome (acute febrile neutrophilic dermatosis). J Am Acad Dermatol 1994, 31, 535-556.

8. Walker D.C., Cohen P.R.: Trimethoprim-sulfamethoxazole-associated acute febrile neutrophilic dermatosis: case report and review of drug-induced Sweet's syndrome. J Am Acad Dermatol 1996, 34, 918-923.

9. Merola J.F.: Sweet syndrome (acute febrile neutrophilic dermatosis): pathogenesis, clinical manifestations, and diagnosis. UpToDate. https://www-1uptodate-1com-1wdagxfsi00c3.han.umb.edu.pl/. Accessed on Jan $15^{\text {th }} 2020$.

10. Cohen P.R:. Sweet's syndrome: a comprehensive review of an acute febrile neutrophilic dermatosis. Orphanet J Rare Dis 2007, 2,34 .

11. Isaac R.E., Sinson D., Jones S..: Sweet syndrome. Br J Oral Maxillofac Surg 2015, 53, 894-895.

12. Bourke J.F., Keohane S., Long C.C., Kemmett D., Davies M., Zaki I., et al.: Sweet's syndrome and malignancy in the U.K. Br J Dermatol 1997, 137, 609-613.

13. Raza S., Kirkland R.S., Patel A.A., Shortridge J.R., Freter C.: Insight into Sweet's syndrome and associated-malignancy: a review of the current literature. Int J Oncol 2013, 42, 1516-1522.

14. Yorio J.T., Mays S.R., Ciurea A.M., Cohen P.R., Wang W.L., Hwu W.J.: Case of vemurafenib-induced Sweet's syndrome. J Dermatol 2014, 41, 817-820.

Received: 19.02 .2020

Accepted: 25.07 .2020

Otrzymano: $19.02 .2020 \mathrm{r}$.

Zaakceptowano: $25.07 .2020 \mathrm{r}$.

How to cite this article

Kozłowska D., Serwin A.B., Flisiak I.: Sweet's syndrome in a 45-year-old patient. Dermatol Rev/Przegl Dermatol 2020, 107, 469-475. DOI: https://doi.org/10.5114/dr.2020.101676. 